\title{
Horticulture in Iowa History
}

\author{
From Lieut. Gov. B. F. Gue Manuscripts
}

These paragraphs collected by former Lieut. Gov. Benj. F. Gue were designated in his record as "Genesis Notes on Horticulture in Iowa History." They are well worth preserving for convenience of future researchers covering the subject.

N. Gambs began his orchard work at Smithland in 1867.

Mr. Everts of Onawa had an eighty acre orchard in the 1860's.

J. W. Ten Brock began the growing of sweet potatoes at Rock Island in 1846.

The Meek brothers planted orchards on the river bottom at Bonaparte in 1841-42.

J. A. Heisler of Mapleton began timber planting in 1868 and planted 60 acres.

Orchard planting in the Cedar Valley began as far north as Floyd county about 1855.

J. C. Wyatt of Orange City picked the first apples grown in Sioux county in 1883 .

The first Osage hedge in Iowa was planted by Col. Brackett in Lee county in 1848.

Old Judge Oliver of Omaha was a pioneer in tree and orchard planting at that point.

The orchard of W. Allen of Sac City bore a thousand bushels of apples as early as 1882 .

Thos. Purdon planted an orchard in Van Buren county, Iowa. Some trees survived down to 1885.

Col. Geo. Davenport was raising an abundance of peaches and grapes on Rock Island as early as 1836.

In 1846 an extreme drouth prevailed. In northeast Iowa not a drop of rain fell from April to November.

Col. E. R. Shankland planted a large orchard in Dubuque county in the 1830's. Some of the trees still survive. 
Suel Foster of Muscatine introduced the hardy $\mathrm{Ca}$ talpa in the 1850's and it had quite a rage for twenty years.

J. A. Dean was one of the horticultural experimenters at Storm Lake beginning his work there in 1872.

The Kaump apple was brought to Iowa by Chas. Waters now of Oregon, who started a nursery in Odebolt in 1875.

John W. Porter, one of our early nurserymen who gave special attention to evergreens, began work about 1860.

The late Geo. W. Shaw of Decatur county, who made a signal success of orcharding, planted his first trees in 1860 .

John N. Dixon's famous orchard of twelve thousand trees was planted in Mahaska county in 1868, and Dixon died in 1882.

The famous old Des Moines county pear tree was planted by Rev. Daniel Cartwright in 1838. It was still alive at last report.

Senator J. H. Gear says that he remembers seeing the first load of Iowa grown fruit displayed on the streets of Burlington.

In 1878 the American Pomological society met at Rochester; Iowa showed 300 varieties of apples and captured first prize-a big silver medal.

Geo. H. Wright was the first Sioux City nursery man and he planted a cherry orchard, a thousand Early Richmonds in 1875.

Ira Brashears who came to Sanborn in the early 1870's made some large experiments in forestry and fruit growing in O'Brien county.

Robert Avery, pioneer nurseryman and orchardist of Burlington, died in 1879 at a good old age. He was an Iowa leader in the business.

The Cap. Bacon orchard in Harrison county is one of the noted in Iowa. It is on a very high ridge, is 30 years old and has been very successful.

Judge Whiting of Monona county planted 300 thousand 
black walnut trees forty years ago. The present value of that timber is simply enormous.

M. A. Moore of LeMars made the first heavy venture in evergreen planting in his section in 1881. He planted twelve hundred trees of eight different sorts.

C. A. Mosier of Des Moines used to tell how in 1867 he shot in the wing a yellow pelican in Storm Lake. As he tried to capture it, the bird seized his arm.

Dr. Weed, the Muscatine pioneer, came to Iowa in 1839 and began the nursery business at once and in four years he was growing 300 varieties of apples, 150 of pears and 90 of peaches.

A French trader, Louis Tesson, located in what is now Lee county in 1799. He brought seedling apple trees from St. Charles, Mo., probably the first ever planted in the state.

Enoch Meade came to Davenport in the fall of 1838 . His first orchard was planted in 1840, with trees from Indiana. When eighty years old, he said if he could live his life over, he would devote it to horticultural work.

The first permanent settlement of Dubuque was made in 1833, and a bearing apple was found in what is now Moslem township. The size of the tree growing among white oaks would indicate an age of 30 to 40 years. This would bring the planting of the tree back to 1800 , the time of Julien Dubuque. This tree stood until 1888 when a tornado broke it off six feet from the ground.

\section{Manliness and Mettle in Saving}

Savings represent much more than mere money value. They are the proof that the saver is worth something in himself. Any fool can waste; any fool can muddle; but it takes something more of a man to save and the more he saves the more of a man he makes of himself. Waste and extravagance unsettle a man's mind for every crisis; thrift, which means some form of self-restraint, steadies it.-Rudyard Kipling. 
Copyright of Annals of Iowa is the property of State of Iowa, by \& through the State Historical Society of Iowa and its content may not be copied or emailed to multiple sites or posted to a listserv without the copyright holder's express written permission. However, users may print, download, or email articles for individual use. 